\title{
The bisphosphonate pamidronate induces apoptosis in human melanoma cells in vitro
}

\author{
C Riebeling',2, A-M Forsea', M Raisova', CE Orfanos' and CC Geilen*,1 \\ 'Department of Dermatology, University Medical Center Benjamin Franklin, The Free University of Berlin, Fabeckstr. 60-62, 14 195-Berlin, Germany
}

Pamidronate belongs to the class of nitrogen-containing bisphosphonates that are potent inhibitors of bone resorption frequently used for the treatment of osteoporosis and cancer-induced osteolysis. The inhibition of osteoclasts' growth has been suggested as the main mechanism of the inhibitory effect of pamidronate on bone metastases. Recent findings indicated that bisphosphonates also have a direct apoptotic effect on other types of tumour cells. Nitrogen-containing bisphosphonates were shown to inhibit farnesyl diphosphate synthase, thus blocking the synthesis of higher isoprenoids. By this mechanism they inactivate monomeric G-proteins of the Ras and Rho families for which prenylation is a functional requirement. On the background of the known key role of G-proteins in tumorigenesis, we investigated a possible beneficial use of pamidronate in the treatment of malignant melanoma. Our results indicate that pamidronate inhibits the cell growth and induces apoptosis in human melanoma cells in vitro. Susceptibility to pamidronate did not correlate to CD95 ligand sensitivity or p53 mutational status. Furthermore it is interesting to note that overexpression of bcl-2 did not abolish pamidronate-induced apoptosis. These data suggests that pamidronate has a direct anti-tumour effect on malignant melanoma cells, independently of the Bax/Bcl-2 level.

British Journal of Cancer (2002) 87, 366-37I. doi:I0.1038/sj.bjc.6600476 www.bjcancer.com

(C) 2002 Cancer Research UK

Keywords: bisphosphonates; pamidronate; Rho proteins; melanoma; apoptosis

At present, melanoma belongs to the most malignant tumours of the skin and mucous membranes due to its aggressive biological behaviour and tendency to generate early metastases. Malignant melanoma is characterised by its relatively high therapeutical resistance (Serrone and Hersey, 1999). Therefore, new therapeutical strategies need to be established.

Monomeric G-proteins of the Ras and Rho families have been shown to be involved in tumorigenesis and metastasis. Both Ras and Rho GTPases are involved in key cellular processes, such as reorganisation of the cytoskeleton, membrane trafficking, lipid metabolism, transcriptional regulation, cell growth, and apoptosis (Aznar and Lacal, 2001). However, overexpression or constitutive activation caused by mutations, rendering them insensitive to regulatory signals reveal the negative aspects of these multifunctional proteins. The dysregulation of these GTPases triggers specific signals that provoke uncontrolled cell growth, enhanced angiogenesis, inhibition of apoptosis, and genetic instability, all main aspects of tumour development. Moreover, Rho family proteins are engaged in regulation of the cytoskeleton and remodelling of cytoarchitecture, which is a requirement of metastasis. Interestingly, enhanced expression of several Rho family members was observed in metastatic tumour cells (Suwa et al, 1998; Fritz et al, 1999; Clark et al, 2000). Recently, it was described that ectopic overexpression of RhoC in A375 melanoma cell line was sufficient to create a highly metastatic phenotype (Clark et al, 2000).

\footnotetext{
*Correspondence: CC Geilen; E-mail: ccgeilen@zedat.fu-berlin.de

${ }^{2}$ Current address: Department of Biological Chemistry, Weizmann Institute of Science, Rehovot 76100, Israel

Received 3 December 200 I; revised 22 April 2002; accepted 10 May 2002
}

For monomeric G-proteins of the Ras and the Rho families prenylation is a functional requirement. The members of the Ras superfamily are acylated and/or prenylated; the acyl/prenyl residues function as membrane anchors when the G-proteins are released from their complex with a guanine nucleotide dissociation inhibitor. Recently, nitrogen-containing bisphosphonates were shown to specifically inhibit farnesyl diphosphate synthase (van Beek et al, 1999; Bergstrom et al, 2000), the enzyme that executes the initial condensation of isopentenyl diphosphate and dimethylallyl diphosphate thereby inhibiting protein prenylation (Luckman et al, 1998). Thus, nitrogen-containing bisphosphonates interfere with membrane localization of these proteins and may abolish signalmediation which can be of use in countering effects of their overexpression or mutation.

Bisphosphonates are used for the treatment of bone metastases and were initially thought to act via an inhibition of formation of osteoclasts from immature precursor cells or direct inhibition of resorption via induction of apoptosis in mature osteoclasts (Hughes et al, 1995). Recently, evidence accumulated that bisphosphonates including pamidronate are potent inducers of apoptosis in several cancer cell types such as myeloma (Shipman et al, 1997; Aparicio et al, 1998), breast cancer (Senaratne et al, 2000) and prostate cancer (Lee et al, 2001) but also in macrophage cell lines (Rogers et al, 1996) and epithelial cell lines (Twiss et al, 1999). These data indicate that the beneficial effect of bisphosphonates may result from a direct anti-tumour activity that may affect a broad range of metastasing tumours.

In the present study, we demonstrate that micromolar concentrations of pamidronate inhibit cell proliferation and induce apoptosis in different melanoma cell lines. The susceptibility to CD95 ligand or the mutational status of p53 did not correlate with the sensitivity to pamidronate. Moreover, overexpression of bcl-2 
did not rescue the cells from pamidronate-induced apoptosis. Nevertheless, the apoptotic effect can be partially abolished by coincubation with farnesol or geranylgeraniol confirming the specific effect of pamidronate on inhibition of prenylation.

\section{MATERIALS AND METHODS}

\section{Materials}

Pamidronate (3-amino-1-hydroxy-propylidene-1,1-bisphosphonate) was purchased from Novartis Pharmaceuticals Limited (Basel, Switzerland). Anti-caspase-3 antibodies (rabbit) were obtained from Pharmingen (Hamburg, Germany) and horseradish peroxidase-conjugated secondary antibodies were purchased from Dako (Hamburg, Germany). Farnesol and geranylgeraniol were obtained from Sigma (Munich, Germany).

\section{Cell culture}

A375 cells (Giard et al, 1973) originate from primary tumour and Mel2A (Bruggen et al, 1981), MeWo (Bean et al, 1975) and SkMel23 (Carey et al, 1976) originate from metastases. The two melanoma cell populations M186 and M221 were obtained from patients with histologically confirmed metastatic melanoma by surgical intervention. The generation and functionality of A375/pIRES and A375/mbcl-2 was described recently (Raisova et al, 2001). Melanoma cells were grown in 90\% Dulbecco's Modified Eagle's Medium (DMEM), $10 \%$ heat-inactivated foetal calf serum and supplemented with penicillin $\left(100 \mathrm{IU} \mathrm{ml}^{-1}\right)$ and streptomycin $\left(100 \mu \mathrm{g} \mathrm{ml}^{-1}\right)$ in $75 \mathrm{~cm}^{2}$ tissue culture flasks (Nunc, Wiesbaden, Germany). Prior to the experiments, the cell lines were cultured for five passages under the same seeding and growth conditions so as to achieve a comparable growth behaviour. DMEM was purchased from Life Technologies (Eggenstein, Germany); further cell culture reagents were obtained from Seromed-Biochrom (Berlin, Germany).

\section{Cytotoxicity assay}

Cytotoxicity of pamidronate was determined by the release of lactate dehydrogenase from the cytosol of damaged cells using an LDH cytotoxicity detection kit (Roche Diagnostics, Mannheim, Germany). Melanoma cells were seeded at a density of 40000 cells per $\mathrm{cm}^{2}$ and after $36 \mathrm{~h}$ treated with agents as indicated or corresponding solvents as control. After incubation, the cell culture supernatant was removed and clarified by centrifugation at $400 \mathbf{g}$ for $5 \mathrm{~min}$. Of the supernatants, $50 \mu \mathrm{l}$ were transferred to microtiter plates and diluted with $50 \mu \mathrm{l}$ of PBS. After addition of $100 \mu \mathrm{l}$ reaction mixture containing 2-[4-iodophenyl]-3-[4-nitrophenyl]-5phenyl tetrazolium chloride, diaphorase, $\mathrm{NAD}^{+}$and sodium lactate, the samples were incubated for $30 \mathrm{~min}$ at room temperature, protected from light. The extinction at $492 \mathrm{~nm}$ was measured using an ELISA reader. The extinction values of control cells were set as $100 \%$ and the rate of lactate dehydrogenase release from treated cells was calculated as per cent of control.

\section{Cell proliferation assay}

Melanoma cells were seeded at a density of 20000 cells per $\mathrm{cm}^{2}$ and after $36 \mathrm{~h}$ treated with agents as indicated or corresponding solvents as control. Cell proliferation was determined by staining cells with crystal violet as described (Wieder et al, 1998). Briefly, non-adherent cells were washed off and the remaining cells were fixed with $0.1 \mathrm{M}$ glutaraldehyde in PBS for $30 \mathrm{~min}$. After washing, the cells were incubated in $0.2 \mathrm{~mm}$ crystal violet in PBS for $30 \mathrm{~min}$. Unbound dye is washed off and $0.2 \%$ Triton X-100 is added to release bound dye. The extinction of the supernatants at $570 \mathrm{~nm}$ was measured using an ELISA reader. The extinction values of vehicle-treated control cells were set as $100 \%$ and the rate of proliferation of treated cells was calculated as per cent of control.

\section{Cell death detection ELISA}

Melanoma cells were seeded at a density of 40000 cells per $\mathrm{cm}^{2}$ and after $36 \mathrm{~h}$ treated with agents as indicated or corresponding solvents as control. Apoptosis was determined quantitatively by using the Cell Death Detection ELISA ${ }^{\text {Plus }}$ Assay (Roche Diagnostics, Mannheim, Germany). Cells were centrifuged at $150 \mathrm{~g}$ for $5 \mathrm{~min}$ and the supernatant was aspirated. Lysis buffer was added and the cells incubated for $30 \mathrm{~min}$. Then, a clear cytosolic supernatant was prepared by centrifugation at $150 \mathrm{~g}$ for $10 \mathrm{~min}$. Of the respective supernatants, $20 \mu \mathrm{l}$ were added to a streptavidin-coated microtiter plate. After addition of $80 \mu \mathrm{l}$ of a solution containing anti-histonbiotin antibodies and anti-DNA-peroxidase antibodies in incubation buffer, the samples were incubated under moderate shaking for $2 \mathrm{~h}$. Subsequently, the wells were washed three times with incubation buffer, $100 \mu \mathrm{l}$ of substrate solution were added and the plate was incubated for up to $10 \mathrm{~min}$ at room temperature in the dark. The absorption was measured at $405 \mathrm{~nm}$ using an ELISA reader. The values of control cells were set as $100 \%$ and the apoptosis rates of treated cells were calculated as per cent of control.

\section{Immunoblotting}

Cells were seeded at a density of 40000 cells per $\mathrm{cm}^{2}$ in $25 \mathrm{~cm}^{2}$ flasks and after $36 \mathrm{~h}$ treated with agonist or corresponding solvents for controls as stated. Subsequently, cells were scraped on ice in $150 \mu \mathrm{l}$ of $50 \mathrm{~mm}$ Tris. $\mathrm{HCl}, \mathrm{pH} 7.2,150 \mathrm{~mm} \mathrm{NaCl}, 1 \mathrm{~mm}$ EDTA, $1 \%$ Triton X-100, $3.5 \mathrm{~mm}$ SDS, $1 \mathrm{mM}$ PMSF, $10 \mu \mathrm{M}$ leupeptin and $1 \mu \mathrm{M}$ pepstatin. After homogenisation by sonication for $10 \mathrm{~s}$, samples were centrifuged for $10 \mathrm{~min}$ with $400 \mathrm{~g}$ at $4^{\circ} \mathrm{C}$. Aliquots of the supernatant were mixed with SDS sample buffer (Laemmli, 1970) containing $0.1 \mathrm{M}$ DTT instead of $\beta$-mercaptoethanol and denatured for $5 \mathrm{~min}$ at $95^{\circ} \mathrm{C}$. After separation by sodium dodecyl sulphate-polyacrylamide gel electrophoresis (SDS-PAGE) and transfer to nitrocellulose membrane the blot was incubated in PBS containing 3\% non-fat dried milk and $0.1 \%$ Tween 20 for $20 \mathrm{~min}$ to block nonspecific binding. The membrane was then incubated with anti-caspase- 3 antibodies $1: 2000$ in blocking buffer for $2 \mathrm{~h}$. Bound antibodies were detected after washing using $50 \mathrm{ng} \mathrm{ml}^{-1}$ horseradish peroxidase-conjugated secondary antibodies in blocking buffer and the SuperSignal chemiluminescent detection reagent (Pierce, Weiskirchen, Germany). Protein was measured in samples diluted $1: 5$ in $\mathrm{H}_{2} \mathrm{O}$ using the BCA assay (Pierce, Weiskirchen, Germany) with bovine serum albumin as standard.

\section{RESULTS}

\section{Inhibition of melanoma cell proliferation by pamidronate}

To evaluate the effect of pamidronate on melanoma cells, four different cell populations were chosen. A375 and M186 are confirmed to be sensitive to CD95 ligand as well as to ceramide whereas Mel2A and M221 are resistant to these stimuli (Raisova et al, 2000). Treatment with increasing concentrations of pamidronate resulted in a concentration-dependent decrease in cell number as assessed after $48 \mathrm{~h}$ (Figure 1). The greatest reduction in cell numbers was observed at a concentration of $100 \mu \mathrm{M}$ pamidronate for A375, M186 and M221. Cell numbers were significantly reduced in the CD95 ligand-sensitive cell lines A375 with $83 \pm 4 \%$ of control and M186 with $89 \pm 4 \%$ of control as well as in the CD95 ligand-resistant M221 with $76 \pm 4 \%$ of control. Cytotoxicity was excluded by measurement of $\mathrm{LDH}$ release into the cell culture supernatant. Higher concentrations of $250 \mu \mathrm{M}$ pamidronate 


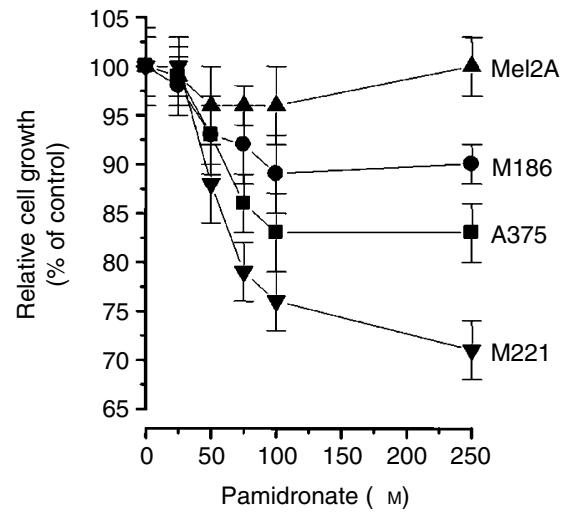

Figure I Effect of pamidronate on melanoma cell proliferation. A375, MI86, Mel2A and M22I melanoma cells were seeded at a density of 20000 cells per $\mathrm{cm}^{2}$ and after $36 \mathrm{~h}$ treated with indicated concentrations of pamidronate or vehicle control for $48 \mathrm{~h}$. Proliferation was measured using crystal violet staining of adherent cells. Cell growth of control cells was set as $100 \%$ and proliferation of treated cells was calculated as a percentage of control. Values represent the mean of four experiments \pm s.d.

did not further reduce cell numbers. In contrast, the proliferation of the CD95 ligand-resistant cell line Mel2A was not affected by pamidronate at any of the used concentrations. These data suggest that the observed effect on cell number is due to growth inhibition and not primary cytotoxicity of pamidronate.

\section{Apoptosis in melanoma cells after pamidronate treatment}

One of the key features of apoptosis is the controlled degradation of nuclear DNA, resulting in histone-bound DNA fragments released into the cytoplasm of the cell. An ELISA assay was used to measure these nucleosomes to achieve a quantification of apoptosis. Treatment of melanoma cells with different concentrations of pamidronate for $24 \mathrm{~h}$ led to a concentration-dependent increase of DNA-fragmentation. As observed for inhibition of proliferation, the effect was greatest with $100 \mu \mathrm{M}$ pamidronate. The CD95 ligand-sensitive cell lines A375 and M186 showed an increase of DNA-fragmentation after treatment with $100 \mu \mathrm{M}$ pamidronate for $24 \mathrm{~h}$ to $330 \pm 20 \%$ of control and $154 \pm 5 \%$ of control, respectively (Figure 2).

Induction of DNA-fragmentation was also shown in the CD95 ligand-resistant cell line M221 with $162 \pm 16 \%$ of control. However, in agreement with the absence of an effect on cell number, the CD95 ligand-resistant cell line Mel2A was also unaffected by pamidronate treatment in respect to DNA-fragmentation.

In contrast to pamidronate, clodronate, a non-amino bisphosphonate showed no effect on proliferation and apoptosis induction in melanoma cell lines at the same concentration range (data not shown). It is interesting to note that incubation of melanoma cells with $100 \mu \mathrm{M}$ pamidronate for only $6 \mathrm{~h}$, followed by an $18 \mathrm{~h}$ medium chase, resulted in nearly the same apoptotic effect as the $24 \mathrm{~h}$ incubation with the drug (Figure 3). This short time effect would correspond to the peak levels of circulating bisphosphonate observed in clinical practice.

In order to investigate a possible synergistic effect of pamidronate and DTIC, a standard chemotherapeutical agent used in melanoma, A375 and M186 melanoma cell lines were incubated for $24 \mathrm{~h}$ with $100 \mu \mathrm{m}$ pamidronate, with $5 \mu \mathrm{g} \mathrm{ml}{ }^{-1}$ DTIC and with pamidronate plus DTIC, respectively. These experiments indicate that $100 \mu \mathrm{M}$ pamidronate has a greater proapoptotic effect than $5 \mu \mathrm{g} \mathrm{ml}^{-1}$ DTIC. However, the combination of both compounds failed to show any synergistic or additive effect in apoptosis induction. The results were similar in the two cell lines studied; the results in A375 are shown in Figure 4.

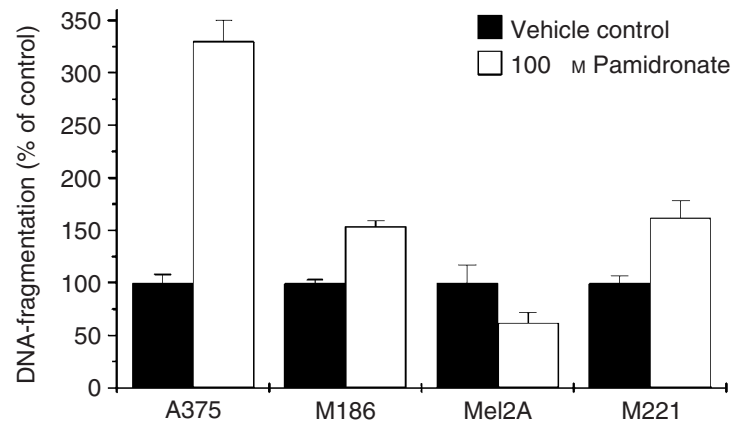

Figure 2 Apoptosis of melanoma cells after pamidronate treatment. A375, MI86, Mel2A and M22I melanoma cells were seeded at a density of 40000 cells per $\mathrm{cm}^{2}$ and after $36 \mathrm{~h}$ treated with vehicle control or $100 \mu \mathrm{M}$ pamidronate for $24 \mathrm{~h}$. DNA-fragmentation was quantified using an enzyme-linked immunoassay detecting cytoplasmic nucleosomes DNA-fragmentation of control cells was set as 100\% and DNA-fragmentation of treated cells was calculated as a percentage of control. Values represent the mean of four experiments \pm s.d.

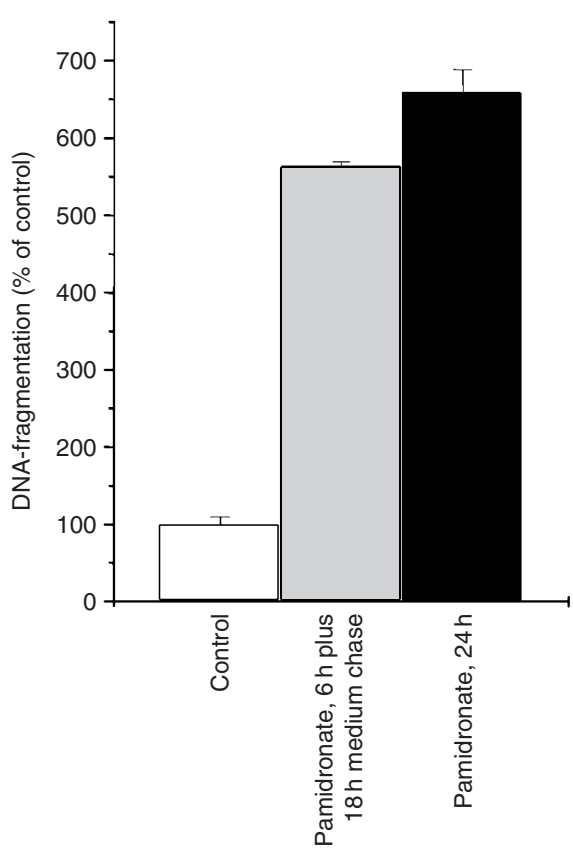

Figure 3 Apoptosis after short term exposure of A375 cells to pamidronate. A375 melanoma cells were seeded at a density of 40000 cells per $\mathrm{cm}^{2}$ and the next day treated with vehicle or $100 \mu \mathrm{M}$ pamidronate. Cells were either treated for $6 \mathrm{~h}$ with pamidronate, after which drug-containing medium was replaced with fresh culture medium, and the cells were further incubated for another $18 \mathrm{~h}$ or incubated with the drug containing medium for $24 \mathrm{~h}$. Apoptosis was then measured as DNA-fragmentation using an enzyme-linked immunoassay detecting cytoplasmic nucleosomes. DNAfragmentation of control cells was set as 100\% and DNA-fragmentation of treated cells was calculated as a percentage of control. Values represent the mean of four experiments \pm s.d.

\section{Caspase-3 is activated in pamidronate-induced apoptosis}

Activation of the executor-caspases $-3,-6$ or -7 is a further key-step in apoptosis. Their activation by proteolytic processing is the point-of-no-return in the commitment to apoptosis. Western blot was performed using anti caspase- 3 antibodies that detect the proenzyme and cleaved enzyme forms. Cells were treated with $100 \mu \mathrm{M}$ pamidronate or vehicle for $24 \mathrm{~h}$ and in case of A375 with the CD95-agonistic monoclonal antibody $\mathrm{CH}-11$ as a positive 


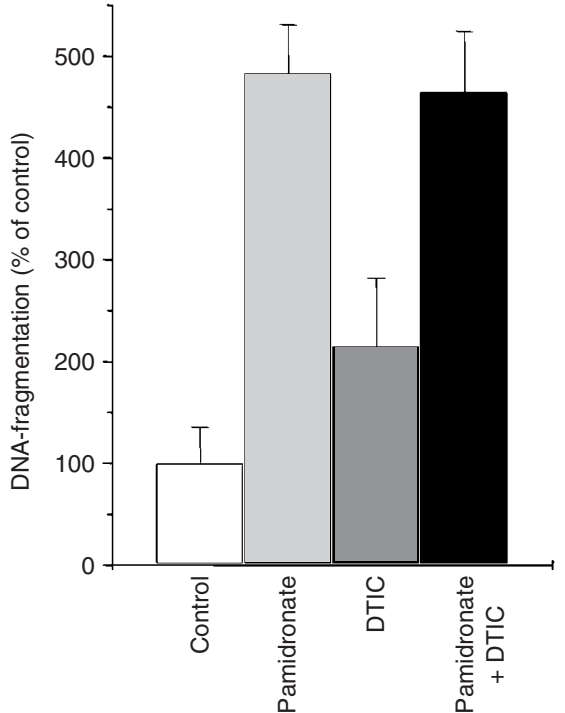

Figure 4 Effect of combination of pamidronate with DTIC. A375 melanoma cells were seeded at a density of 40000 cells per $\mathrm{cm}^{2}$ and the next day treated with $100 \mu \mathrm{M}$ Pamidronate, $5 \mu \mathrm{g} \mathrm{ml}{ }^{-1}$ DTIC or both. After 24 h of incubation apoptosis was measured. DNA-fragmentation of control cells was set as 100\% and DNA-fragmentation of treated cells was calculated as a percentage of control. Values represent the mean of four experiments \pm s.d.

control. Activation of procaspase- 3 is detected by appearance of cleaved forms of 20 and $17 \mathrm{kDa}$. The CD95 ligand-sensitive cell lines A375 and M186 show cleaved forms after pamidronate-treatment but not in vehicle controls. This is confirmed by cleavage of procaspase-3 after treatment of A375 with CH-11. M221, a CD95 ligand-resistant cell line exhibits cleaved forms of caspase-3 after pamidronate-treatment. Furthermore, in correlation to the results for cell proliferation and DNA-fragmentation, the CD95 ligandresistant cell line Mel2A shows no activation of caspase-3 (Figure $5)$.

\section{p53 mutation or bcl-2 overexpression do not abolish pamidronate-induced apoptosis}

Two frequent mechanisms by which tumour cells achieve chemoresistance were tested for their effect on pamidronate-induced apoptosis. The two melanoma cell lines MeWo and SkMel23 harbour a mutated p53 gene (Raisova et al, 2001). Mutations in this gene can render tumour cells insensitive to radiotherapy and chemotherapy. In agreement, these cell lines were shown to be resistant to CD95- and ceramide-induced apoptosis (Raisova et al, 2001). The cells were treated for $24 \mathrm{~h}$ with $100 \mu \mathrm{M}$ pamidronate and apoptosis was quantified in terms of DNA-fragmentation. Both cell lines were sensitive to pamidronate treatment with DNA-fragmentation of $320 \pm 20 \%$ of control and $450 \pm 50 \%$ of control for MeWo and SkMel23, respectively (Figure 6A).

Shifting the ratio of the proapoptotic protein bax to the antiapoptotic protein bcl-2 is another mechanism by which tumour cells escape the immune system and achieve resistance against drugs entering the mitochondrial apoptotic pathway. This resistance can be mimicked in cell culture by ectopic overexpression of bcl-2. A375 cells stably overexpressing murine bcl-2 $\alpha$ (A375/ mbcl-2) and A375 transfected with vector only (A375/pIRES) as control were treated for $24 \mathrm{~h}$ with $100 \mu \mathrm{M}$ pamidronate. A375/ mbcl-2 in contrast to A375/pIRES were shown to be resistant to CD95- as well as ceramide-induced apoptosis (Raisova et al, 2001). However, $100 \mu \mathrm{M}$ pamidronate induced DNA-fragmentation

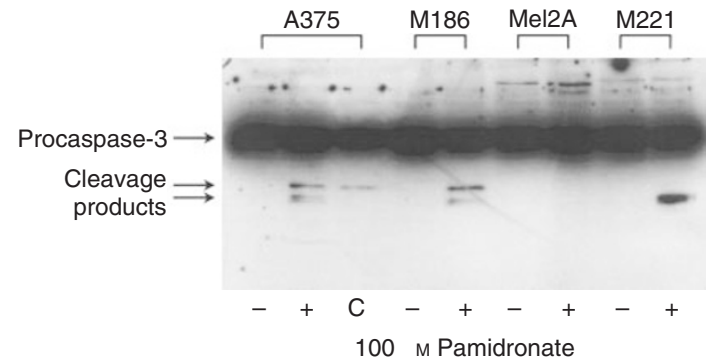

Figure 5 Procaspase- 3 cleavage upon pamidronate treatment in melanoma cells. A375, MI86, Mel2A and M22I melanoma cells were seeded at a density of 40000 cells per $\mathrm{cm}^{2}$ and after $36 \mathrm{~h}$ treated with $100 \mu \mathrm{M}$ pamidronate $(+)$, vehicle control (-) or I $\mu \mathrm{g} \mathrm{ml}^{-1}$ of the CD95-agonistic monoclonal antibody $\mathrm{CH}-\mathrm{II}$ (C) as a positive control for $24 \mathrm{~h}$. Whole cell lysates were prepared and $50 \mu \mathrm{g}$ of each were separated on a I5\% SDS PAGE. After transfer to nitrocellulose the membrane was probed with anti caspase-3 antibodies recognising procaspase-3 and cleavage products forming active caspase-3 respectively. Immunocomplexes were detected using Super Signal chemiluminescence reagent.

\section{A}

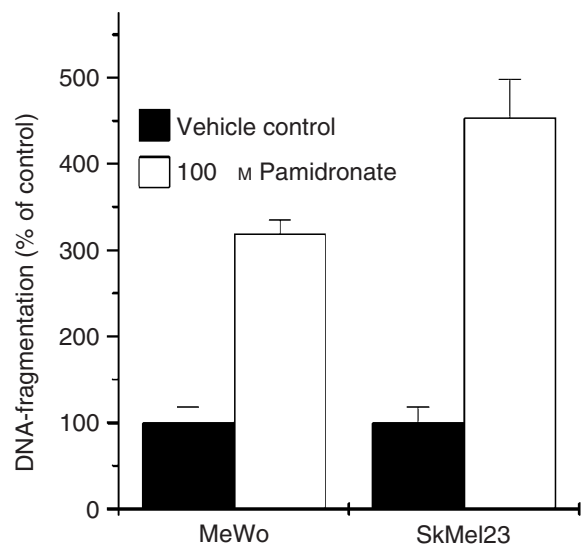

B

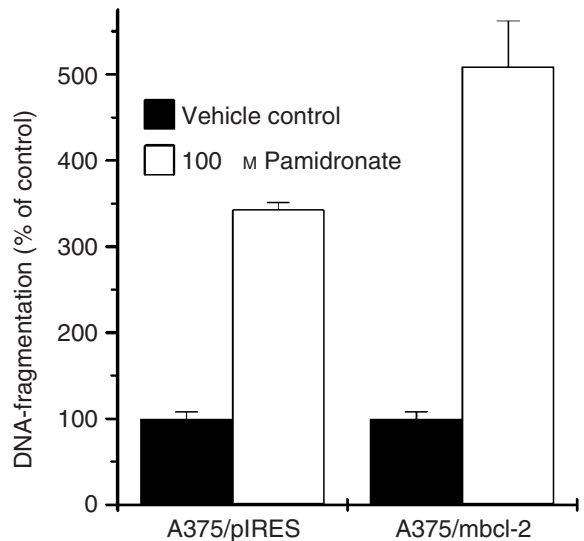

Figure 6 Induction of apoptosis in p53-mutated and bcl-2 overexpressing melanoma cells by pamidronate. (A) The p53-mutated cell lines MeWo and SkMel23 and (B) the mock-transfected A375/pIRES and the bcl-2 overexpressing A375/mbcl-2 were seeded at a density of 40000 cells per $\mathrm{cm}^{2}$ and after $36 \mathrm{~h}$ treated with vehicle control or $100 \mu \mathrm{M}$ pamidronate for $24 \mathrm{~h}$. DNA-fragmentation was quantified using an enzyme-linked immunoassay detecting cytoplasmic nucleosomes. DNA-fragmentation of control cells was set as 100\% and DNA-fragmentation of treated cells was calculated as a percentage of control. Values represent the mean of four experiments \pm s.d. 
in A375/pIRES with $343 \pm 8 \%$ of control as well as in A375/mbcl-2 with $509 \pm 53 \%$ of control (Figure 6B).

\section{Geranylgeraniol abolishes pamidronate-induced apoptosis}

The most prominent effect of pamidronate is the inhibition of farnesyl diphosphate synthase, abolishing all isoprenoid biosynthesis (van Beek et al, 1999). To specifically circumvent the effect of pamidronate on isoprenoid biosynthesis, cells were supplemented with farnesol or geranylgeraniol. Farnesol can be used as a precursor for synthesis of all higher isoprenoids and protein-farnesylation whereas geranylgeraniol only supplies ubiquinone biosynthesis and protein-geranylgeranylation. The addition of increasing concentrations of either farnesol or geranylgeraniol in the presence of pamidronate reduced pamidronate-induced DNAfragmentation in A375 cells in a concentration-dependent manner (Figure 7). Farnesol or geranylgeraniol at a concentration of $10 \mu \mathrm{M}$ had no impact on pamidronate-induced apoptosis. At a concentration of $50 \mu \mathrm{M}$, farnesol reduced the apoptotic effect of pamidronate by about $50 \%$ and $50 \mu \mathrm{M}$ geranylgeraniol reduced DNA-fragmentation induced by pamidronate by $75 \%$. However, higher concentrations of $100 \mu \mathrm{M}$ only slightly further decreased pamidronate-induced apoptosis.

\section{DISCUSSION}

In this study, we demonstrate that treatment of melanoma cell lines with the nitrogen-containing bisphosphonate pamidronate in vitro induces apoptosis and inhibits proliferation of human melanoma cells in a concentration-dependent manner. In contrast, clodronate, a non-amino bisphosphonate, had no effect in melanoma cell lines at the same concentration range. Furthermore, induction of apoptotic DNA-fragmentation was paralleled by caspase-3 cleavage in these cell lines. The CD95 ligand-sensitive cell lines A375 and M186 as well as the CD95 ligand-resistant cell lines M221, MeWo and SkMel23 showed DNA-fragmentation upon treatment with $100 \mu \mathrm{M}$ pamidronate. This concentration of pamidronate has also been shown to induce apoptosis in other cell lines, e.g. myeloma (Shipman et al, 1997), breast cancer (Senaratne et al, 2000), and prostate cancer (Lee et al, 2001). However, the CD95 ligand-resistant cell line Mel2A was not affected by this bisphosphonate. A specific apoptotic effect of pamidronate was further confirmed by the observation that caspase- 3 is cleaved and therefore activated in pamidronate-treated cells. Again, Mel2A showed no caspase-3 processing upon treatment with pamidronate. MeWo and SkMel23 harbour a mutated p53 gene that is a rather rare event in melanoma. Other tumours show frequent mutation in this gene, which often leads to resistance against chemotherapy. The susceptibility of these cell lines to pamidronate suggests a p53-independent pathway of apoptosis-induction for this drug. Experimental settings using bcl-2 antisense oligonucleotide therapy revealed an inverse correlation between chemosensitivity of melanoma cells and bcl-2 levels (Jansen et al, 1998). These findings indicate that the bcl-2 protein levels contribute to drug resistance. Our investigations of a bcl-2 overexpressing A375 cell line revealed that bcl-2 overexpression could not abolish the apoptosis triggered by pamidronate. This proposes that pamidronate-induced apoptosis is a process independent of mitochondrial activation.

Nitrogen containing bisphosphonates were shown to inhibit the farnesyl diphosphate synthase probably by mimicking the diphosphate moiety (van Beek et al, 1999). They are therefore inhibitors of the synthesis of higher isoprenoids like geranylgeranyl diphosphate. The prenylation of monomeric G-proteins such as members of the Ras superfamily like Rho proteins was shown to be reduced by bisphosphonate treatment. Geranylgeranylation of these proteins is required for their proper membrane association and hence activity. Rho family proteins are engaged in cytoskeletal

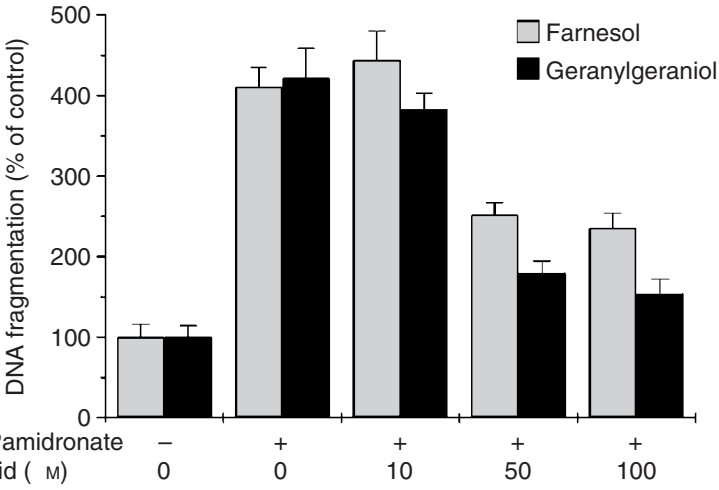

Figure 7 Effect of isoprenoids on pamidronate-induced apoptosis in melanoma cells. A375 melanoma cells were seeded at a density of 40000 cells per $\mathrm{cm}^{2}$ and after $36 \mathrm{~h}$ treated with $100 \mu \mathrm{M}$ pamidronate in the presence of indicated concentrations of farnesol, geranylgeraniol or vehicle control for $24 \mathrm{~h}$. DNA-fragmentation was quantified as cytoplasmic nucleosomes using an enzyme-linked immunoassay. DNA-fragmentation of control cells was set as 100\% and DNA-fragmentation of treated cells was calculated as a percentage of control. Values represent the mean of four experiments \pm s.d.

reorganisation and enhanced expression of several isoforms was observed in metastatic tumour cells (Fritz et al, 1999). Moreover, ectopic overexpression of the Rho protein RhoC in A375 melanoma cells was sufficient to create a highly metastatic phenotype (Clark et al, 2000). Therefore, the inhibition of Rho proteins might provide a possibility to reduce metastasis through interference with this pathway. The involvement of the inhibitory effect of pamidronate on isoprenoid biosynthesis in induction of apoptosis was tested using farnesol and geranylgeraniol to circumvent the blockade of geraniol synthesis. Geranylgeraniol was more potent in abolishing pamidronate induced-apoptosis than farnesol. Supplying geranylgeraniol reduced apoptosis by about $75 \%$, suggesting geranylgeranylated proteins such as Rho proteins to be the main target of the pamidronate-effect. The participation of the mevalonate pathway in bisphosphonate-induced apoptosis was also demonstrated in mouse macrophages (Luckman et al, 1998) and human myeloma cells (Shipman et al, 1998). An alternative mechanism of action has been described for the non-amino bisphosphonate clodronate (Frith et al, 1997). The incorporation of bisphosphonates into ATP generates non-hydrolyzable toxic analogues. This pathway may also in part account for the action of nitrogen-containing bisphosphonates. However, in our experiments, clodronate in the same concentration range as pamidronate failed to induce apoptosis in melanoma cell lines

Nitrogen-containing bisphosphonates with a similar bone protective potency to pamidronate at concentrations of several magnitudes less than required for pamidronate treatment have been described (Rogers et al, 2000). Different bisphosphonates are now introduced in clinical practice. For the use as chemotherapy, a major drawback of bisphosphonates is their high affinity to hydroxyapatite on the bone surface, which makes them preferentially delivered to sites of increased bone formation or resorption. Animal studies revealed that the skeletal uptake of alendronate reaches $90 \%$ of peak values within $1 \mathrm{~h}$ of intravenous or oral administration (Lin et al, 1991). This could limit their therapeutic applicability to the treatment of bone metastasis. Nevertheless, the issue of a survival benefit is still controversial (Wingen et al, 1986; Hall and Stoica, 1994; Diel et al, 1998). Therefore, new derivates with an increased bioavailability are required to extend the therapeutic spectrum of bisphosphonates.

Our findings show for the first time that pamidronate has a direct effect on melanoma cells, which is not blocked by overex- 
pression of bcl-2. This data suggests that nitrogen-containing bisphosphonates could be a promising novel therapeutic class for the treatment and/or prevention of melanoma metastases. Although our results suggest that pamidronate has no synergistic effect with the classical chemotherapeutical agents such as DTIC, possible alternative combinations of chemotherapy and bisphosphonates should be further investigated. Further studies are also necessary to elucidate the underlying mechanism of their proapoptotic effect in more detail and to establish the potential

\section{REFERENCES}

Aparicio A, Gardner A, Tu Y, Savage A, Berenson J, Lichtenstein A (1998) In vitro cytoreductive effects on multiple myeloma cells induced by bisphosphonates. Leukemia 12: 220-229

Aznar S, Lacal JC (2001) Rho signals to cell growth and apoptosis. Cancer Lett 165: $1-10$

Bean MA, Bloom BR, Herberman RB, Old LJ, Oettgen HF, Klein G, Terry WD (1975) Cell-mediated cytotoxicity for bladder carcinoma: evaluation of a workshop. Cancer Res 35: 2902-2913

Bergstrom JD, Bostedor RG, Masarachia PJ, Reszka AA, Rodan G (2000) Alendronate is a specific, nanomolar inhibitor of farnesyl diphosphate synthase. Arch Biochem Biophys 373: $231-241$

Bruggen J, Fogh J, Sorg C (1981) Tumor production in the nude mouse, fibrinolytic activity and cross- reactivity with antimelanoma sera of various human tumor cell lines. J Cancer Res Clin Oncol 102: 141-152

Carey TE, Takahashi T, Resnick LA, Oettgen HF, Old LJ (1976) Cell surface antigens of human malignant melanoma: mixed hemadsorption assays for humoral immunity to cultured autologous melanoma cells. Proc Natl Acad Sci USA 73: $3278-3282$

Clark EA, Golub TR, Lander ES, Hynes RO (2000) Genomic analysis of metastasis reveals an essential role for RhoC. Nature 406: 532-535

Diel IJ, Solomayer EF, Costa SD, Gollan C, Goerner R, Wallwiener D, Kaufmann M, Bastert G (1998) Reduction in new metastases in breast cancer with adjuvant clodronate treatment. $N$ Engl J Med 339: 357-363

Frith JC, Monkkonen J, Blackburn GM, Russell RG, Rogers MJ (1997) Clodronate and liposome-encapsulated clodronate are metabolized to a toxic ATP analog, adenosine 5' -(beta, gamma-dichloromethylene) triphosphate, by mammalian cells in vitro. J Bone Miner Res 12: $1358-1367$

Fritz G, Just I, Kaina B (1999) Rho GTPases are over-expressed in human tumors. Int J Cancer 81: $682-687$

Giard DJ, Aaronson SA, Todaro GJ, Arnstein P, Kersey JH, Dosik H, Parks WP (1973) In vitro cultivation of human tumors: establishment of cell lines derived from a series of solid tumors. J Natl Cancer Inst 51: $1417-$ 1423

Hall DG, Stoica G (1994) Effect of the bisphosphonate risedronate on bone metastases in a rat mammary adenocarcinoma model system. J Bone Miner Res 9: $221-230$

Hughes DE, Wright KR, Uy HL, Sasaki A, Yoneda T, Roodman GD, Mundy GR, Boyce BF (1995) Bisphosphonates promote apoptosis in murine osteoclasts in vitro and in vivo. J Bone Miner Res 10: 1478- 1487

Jansen B, Schlagbauer-Wadl H, Brown BD, Bryan RN, van Elsas A, Muller M, Wolff K, Eichler HG, Pehamberger H (1998) bcl-2 antisense therapy chemosensitizes human melanoma in SCID mice. Nat Med 4: $232-234$

Laemmli UK (1970) Cleavage of structural proteins during the assembly of the head of bacteriophage T4. Nature 227: 680-685

Lee MV, Fong EM, Singer FR, Guenette RS (2001) Bisphosphonate treatment inhibits the growth of prostate cancer cells. Cancer Res 61: 2602-2608

Lin JH, Duggan DE, Chen IW, Ellsworth RL (1991) Physiological disposition of alendronate, a potent anti-osteolytic bisphosphonate, in laboratory animals. Drug Metab Dispos 19: 926-932 antitumoural role of different bisphosphonate derivatives in human melanoma.

\section{ACKNOWLEDGEMENTS}

This study was supported by grants from the Deutsche Forschungsgemeinschaft Ge641/5-5 and SFB 366. A-M Forsea was a recipient of a scholarship of the Berliner Stiftung für Dermatologie.
Luckman SP, Hughes DE, Coxon FP, Graham R, Russell G, Rogers MJ (1998) Nitrogen-containing bisphosphonates inhibit the mevalonate pathway and prevent post-translational prenylation of GTP-binding proteins, including Ras. J Bone Miner Res 13: $581-589$

Raisova M, Bektas M, Wieder T, Daniel P, Eberle J, Orfanos CE, Geilen CC (2000) Resistance to CD95/Fas-induced and ceramide-mediated apoptosis of human melanoma cells is caused by a defective mitochondrial cytochrome c release. FEBS Lett 473: $27-32$

Raisova M, Hossini AM, Eberle J, Riebeling C, Wieder T, Sturm I, Daniel PT, Orfanos CE, Geilen CC (2001) The Bax/Bcl-2 ratio determines the susceptibility of human melanoma cells to CD95/Fas-mediated apoptosis. J Invest Dermatol 117: $333-340$

Rogers MJ, Chilton KM, Coxon FP, Lawry J, Smith MO, Suri S, Russell RG (1996) Bisphosphonates induce apoptosis in mouse macrophage-like cells in vitro by a nitric oxide-independent mechanism. J Bone Miner Res 11: $1482-1491$

Rogers MJ, Gordon S, Benford HL, Coxon FP, Luckman SP, Monkkonen J, Frith JC (2000) Cellular and molecular mechanisms of action of bisphosphonates. Cancer 88: 2961-2978

Senaratne SG, Pirianov G, Mansi JL, Arnett TR, Colston KW (2000) Bisphosphonates induce apoptosis in human breast cancer cell lines. Br J Cancer 82: $1459-1468$

Serrone L, Hersey P (1999) The chemoresistance of human malignant melanoma: an update. Melanoma Res 9: $51-58$

Shipman CM, Croucher PI, Russell RG, Helfrich MH, Rogers MJ (1998) The bisphosphonate incadronate (YM175) causes apoptosis of human myeloma cells in vitro by inhibiting the mevalonate pathway. Cancer Res 58: $5294-5297$

Shipman CM, Rogers MJ, Apperley JF, Russell RG, Croucher PI (1997) Bisphosphonates induce apoptosis in human myeloma cell lines: a novel anti-tumour activity. Br J Haematol 98: 665-672

Suwa H, Ohshio G, Imamura T, Watanabe G, Arii S, Imamura M, Narumiya S, Hiai H, Fukumoto M (1998) Overexpression of the rhoC gene correlates with progression of ductal adenocarcinoma of the pancreas. Br J Cancer 77: $147-152$

Twiss IM, Pas O, Ramp-Koopmanschap W, Den Hartigh J, Vermeij P (1999) The effects of nitrogen-containing bisphosphonates on human epithelial (Caco-2) cells, an in vitro model for intestinal epithelium. J Bone Miner Res 14: $784-791$

van Beek E, Pieterman E, Cohen L, Lowik C, Papapoulos S (1999) Farnesyl pyrophosphate synthase is the molecular target of nitrogen- containing bisphosphonates. Biochem Biophys Res Commun 264: 108-111

Wieder T, Orfanos CE, Geilen CC (1998) Induction of ceramide-mediated apoptosis by the anticancer phospholipid analog, hexadecylphosphocholine. J Biol Chem 273: 11025-11031

Wingen F, Eichmann T, Manegold C, Krempien B (1986) Effects of new bisphosphonic acids on tumor-induced bone destruction in the rat. $J$ Cancer Res Clin Oncol 111: 35-41 